\title{
Therapy-related acute myeloid leukemia following treatment of Iymphoid malignancies
}

\author{
Sarah Bertoli ${ }^{1,2,3}$, Arthur Sterin ${ }^{4}$, Suzanne Tavitian ${ }^{1}$, Lucie Oberic ${ }^{1}$, Loïc Ysebaert S $^{1,2,3}$, \\ Reda Bouabdallah ${ }^{4}$, François Vergez ${ }^{3,5}$, Audrey Sarry ${ }^{1}$, Emilie Bérard ${ }^{6,7}$, Françoise \\ Huguet $^{1}$, Guy Laurent ${ }^{1,2}$, Thomas Prébet ${ }^{4,8}$, Norbert Vey ${ }^{4,8,9, *}$, Christian Récher ${ }^{1,2,3, *}$ \\ ${ }^{1}$ Service d'Hématologie, Centre Hospitalier Universitaire de Toulouse, Institut Universitaire du Cancer de Toulouse Oncopole, \\ Toulouse, France \\ ${ }^{2}$ Université Toulouse III Paul Sabatier, Toulouse, France \\ ${ }^{3}$ Cancer Research Center of Toulouse (CRCT), UMR1037 INSERM, ERL5294 CNRS, Toulouse, France \\ ${ }^{4}$ Service d'Hématologie, Institut Paoli-Calmettes, Marseille, France \\ ${ }^{5}$ Laboratoire d'Hématologie, Centre Hospitalier Universitaire de Toulouse, Institut Universitaire du Cancer de Toulouse \\ Oncopole, Toulouse, France \\ ${ }^{6}$ Service d'Epidémiologie, Centre Hospitalier Universitaire de Toulouse, Toulouse, France \\ 7 UMR 1027, INSERM-Université de Toulouse III, Toulouse, France \\ ${ }^{8}$ Département d'Oncologie Moléculaire, Centre de Recherche en Cancérologie de Marseille (CRCM), Institut Paoli-Calmettes, \\ UMR1068 Inserm, Marseille, France \\ ${ }^{9}$ Aix-Marseille University, Marseille, France \\ *co-senior authors
}

Correspondence to: Christian Récher, email: recher.christian@iuct-oncopole.fr

Keywords: leukemia, therapy-related acute myeloid leukemia, second cancer, lymphoma, chronic lymphocytic leukemia

Received: May 26, $2016 \quad$ Accepted: November 01, $2016 \quad$ Published: November 10, 2016

\section{ABSTRACT}

Therapy-related acute myeloid leukemia (t-AML) is a heterogeneous entity most frequently related to breast cancer or lymphoproliferative diseases (LD). Populationbased studies have reported an increased risk of t-AML after treatment of lymphomas. The aim of this study was to describe the characteristics and outcome of 80 consecutive cases of $t-A M L$ following treatment of LD. $t-A M L$ accounted for $2.3 \%$ of all AML cases, occurred 60 months after LD diagnosis, and were characterized by a high frequency of FAB M6 AML and poor-risk cytogenetic abnormalities. Time to t-AML diagnosis was influenced by patient age, type of $L D$, and treatment. Among the $48 \mathrm{t}-\mathrm{AML}$ patients treated with intensive chemotherapy, median overall survival (OS) was 7.7 months compared to $\mathbf{2 6 . 1}$ months in de novo, $\mathbf{4 . 2}$ months in post-myeloproliferative neoplasm, 9.4 months in post-myelodysplastic syndrome, 8.6 months in post-chronic myelomonocytic leukemia AML, 13.4 months in t-AML secondary to the treatment of solid cancer, and 14.7 months in breast cancer only. OS of post-LD t-AML patients was significantly influenced by age, performance status, myelodysplastic syndrome prior to LD/t-AML, and treatment regimen for LD. Thus, $t-A M L$ following lymphoid malignancies treatment should be considered as very high-risk secondary AML. New treatment strategies in patients with LD/t-AML are needed urgently.

\section{INTRODUCTION}

Therapy-related acute myeloid leukemia (t-AML) is described in the WHO classification [1-2] as AML occurring after a previous cancer whose treatment comprises mainly an alkylating agent, ionizing radiation therapy - giving rise to chromosome 5 or 7 abnormalities, and/or topoisomerase II inhibitor - generating balanced translocations, including $\mathrm{t}(15 ; 17)[3]$ or $11 \mathrm{q} 23[M L L]$ rearrangements among others. The poor prognosis of t-AML was first reported in patients with multiple myeloma treated with melphalan [4]. Subsequently, 
almost all other alkylating agents have been associated with an increased risk of t-AML in patients treated for a wide spectrum of diseases [5] whereas topoisomerase II inhibitors were first associated with secondary AML in children who received epipodophyllotoxins for acute lymphoblastic leukemia [6]. Individualization of this category of AML permitted to emphasize the distinct biological and clinical features of this entity typically characterized by an adverse outcome [7].

Although most of the knowledge of the relationship between prior exposure to anti-cancer therapy and therapy-related AML comes from epidemiological studies, arguments for a direct impact of cytotoxic therapy in leukemogenesis exist. In therapy-related acute promyelocytic leukemia, mitoxantrone, etoposide, and doxorubicin have been shown to induce DNA cleavage at specific genomic hot spot sites in PML and RARA genes, leading to $\mathrm{t}(15 ; 17)$ translocation. Moreover, mitoxantrone has been associated with secondary AML in patients treated for a nonmalignant condition [8]. More recently, it has been shown that cytotoxic therapy favors the expansion of rare hematopoietic stem cells carrying TP53 mutations in a founding clone that expands preferentially after therapy and evolves to leukemia through the accumulation of chromosomal abnormalities found typically in t-AML [9].

The most frequent therapy-related myeloid neoplasms are related to breast cancer and lymphoproliferative diseases (LD) [10-12]. Data from large US population-based cancer registries have shown that $\mathrm{t}$-AML is 4.7 fold more frequent than expected in the general population, which is consistent with other nationwide registries [10-14]. These population-based studies reported an increased risk of t-AML after treatment of non-Hodgkin lymphomas (NHL) (Standardized Incidence Ratio, 5.96 for follicular lymphoma; 4.96 for diffuse large B cell lymphoma) [15]. This risk remains elevated for at least one decade after chronic lymphocytic leukemia (CLL), Hodgkin lymphoma (HL), and NHL treatment $[10,16]$. It has also been described that the risk of AML has significantly increased in the last 30 years after chemotherapy for NHL, remained stable for HL, and decreased for multiple myeloma, consistent with changing practices and differential leukemogenicity of specific therapies [10]. Alkylating agents and topoisomerase II inhibitors have long-standing constituted the backbone of $\mathrm{T}$ or B-cell lymphomas treatments, accounting for a certain proportion of t-AML. More recently, nucleoside analogs - mainly fludarabine - and anti-CD20 monoclonal antibodies - firstly rituximab, among others, have enlarged treatment options and have been used widely, thus improving outcome [17]. Whether this new therapeutic landscape has modified the spectrum of this subset of $\mathrm{t}$-AML remains to be studied in detail.

Since previous neoplasia and treatment are highly heterogeneous in the t-AML category, the aim of this study was to describe the characteristics and outcome of AML following treatment of lymphoid malignancies.

\section{RESULTS}

\section{Characteristics of $\mathrm{LD}$ at diagnosis}

In the 1997-2012 period, 80 consecutive cases of t-AML following treatment of NHL, HL, T-cell lymphoma (TCL), and chronic lymphocytic leukemia (CLL) (thereafter referred as lymphoid diseases; LD) were diagnosed. Median age at LD diagnosis was 60 years (IQR [interquartile range], 48-67). Thirteen patients (16\%) had diffuse large B cell lymphoma (DLBCL), five had mantle cell lymphoma (MCL) (6\%), two had Burkitt-like lymphoma (BL) (3\%), fourteen had follicular lymphoma (FL) (18\%), two had MALT/SALT lymphoma (3\%), one had lymphocytic lymphoma (1\%), 11 had HL (14\%), eight had CLL (10\%), and five had TCL (6\%) (Table 1). The majority of them had advanced stages of disease. The median number of prior LD treatment lines was one (1-6); 30 patients (38\%) had two treatment lines and nine patients $(11 \%)$ had three or more treatment lines. Among the 74 patients who received chemotherapy, 11 (15\%) received a fludarabine-based regimen (all of them in association with an alkylating agent), 34 (46\%) a CHOPlike regimen, 19 (26\%) chlorambucil, and 34 (46\%) rituximab. Autologous stem-cell transplantation (ASCT) was performed in 16 patients $(22 \%)$.

\section{Characteristics of LD-therapy-related AML}

LD-therapy-related AML (LD/t-AML) accounted for $2.3 \%$ of all cases of AML treated with intensive chemotherapy in the studied period. Median time from LD diagnosis to t-AML diagnosis was 60 months (IQR, 31-106). Median age at t-AML diagnosis was 66 years (IQR, 57-71). Characteristics of LD/t-AML are described in Table 2. ECOG performance status was $\geq 2$ in 20 patients (25\%). FAB classification was mainly M2 (36\%), M4 $(16 \%)$, and M6 (11\%). There was no diagnosis of APL. Median WBC at diagnosis was $3.8 \times 10^{9} / \mathrm{L}$ (IQR, 1.7-29.5) and median bone marrow blast was 46\% (IQR, 32-69). Cytogenetic risk was favorable for three patients $(4 \%)$, intermediate for 36 patients (45\%), and adverse for 29 patients $(36 \%)$. $M L L$ rearrangements, chromosome 5 and 7 abnormalities, were observed in 6,16 , and $22 \%$ of cases respectively, whereas $22 \%$ had complex karyotypes and $22 \%$ monosomal karyotypes. These poor-risk cytogenetic abnormalities were two-fold more frequent than in de novo AML (Table 2). The characteristics at diagnosis of de novo AML $(n=829)$, AML secondary to myelodysplastic syndrome, Philadelphia-negative myeloproliferative neoplasm or chronic myelomonocytic leukemia $(n=292)$ and t-AML following treatment of solid cancers $(n=85)$ diagnosed in the 2000-2012 period are presented in Table 2. 
Table 1: Characteristics of previous LD

\begin{tabular}{|c|c|}
\hline Age at LD diagnosis - years (median, IQR) & $60(48-67)$ \\
\hline $\begin{array}{l}\text { Center }-\mathbf{n}(\mathbf{\%}) \\
\text { Toulouse } \\
\text { Marseille }\end{array}$ & $\begin{array}{l}35(44) \\
45(56)\end{array}$ \\
\hline $\begin{array}{l}\text { LD type - n (\%) } \\
\text { Aggressive NHL } \\
\text { DLBCL } \\
\text { MCL } \\
\text { BL } \\
\text { Other } \\
\text { Indolent NHL } \\
\text { FL } \\
\text { Chronic lymphocytic leukemia } \\
\text { MALT/SALT } \\
\text { Lymphocytic } \\
\text { Unknown } \\
\text { Hodgkin lymphoma } \\
\text { T-cell lymphoma } \\
\text { Not known }\end{array}$ & $\begin{array}{c}22(28) \\
13(16) \\
5(6) \\
2(3) \\
2(3) \\
32(40) \\
14(18) \\
8(10) \\
4(5) \\
1(1) \\
1(1) \\
\mathbf{1 1}(\mathbf{1 4 )} \\
\mathbf{5}(6) \\
\mathbf{2}(3)\end{array}$ \\
\hline $\begin{array}{l}\text { Stage at diagnosis }-\mathbf{n}(\mathbf{\%}) \\
\text { Localized }^{*} \\
\text { Advanced } \\
\text { Binet A } \\
\text { Binet B-C } \\
\text { Unknown }\end{array}$ & $\begin{array}{c}14(18) \\
46(58) \\
1(1) \\
5(6) \\
14(18)\end{array}$ \\
\hline $\begin{array}{l}\text { Treatment - n (\%) } \\
\text { Chemotherapy only } \\
\text { Radiotherapy only } \\
\text { Chemotherapy + radiotherapy } \\
\text { R-chemotherapy } \\
\text { R-chemotherapy + radiotherapy } \\
\text { Unknown }\end{array}$ & $\begin{array}{c}80(100) \\
21(26) \\
1(1) \\
19(24) \\
28(33) \\
6(8) \\
5(6)\end{array}$ \\
\hline $\begin{array}{l}\text { Chemotherapy agent }^{* * *} \\
\text { Alkylating agents } \\
\text { Fludarabine-based } \\
\text { CHOP-like } \\
\text { Chlorambucil } \\
\text { Rituximab }\end{array}$ & $\begin{array}{l}66 / 68(97) \\
11 / 68(16) \\
34 / 68(50) \\
19 / 68(28) \\
34 / 70(49)\end{array}$ \\
\hline $\begin{array}{l}\text { No. of treatment lines (median, min-max) } \\
2 \text { lines }-\mathrm{n}(\%) \\
\geq 3 \text { lines }-\mathrm{n}(\%)\end{array}$ & $\begin{array}{l}1(1-6) \\
30(38) \\
9(11)\end{array}$ \\
\hline Autologous stem cell transplantation - n (\%) & $16(20)$ \\
\hline
\end{tabular}

Abbreviations: LD: lymphoid disease; NHL: non-Hodgkin Lymphoma; DLBCL: diffuse large B cell lymphoma; MCL: mantle cell lymphoma; BL: Burkitt-like; FL: follicular lymphoma; NOS: not otherwise specified.

${ }^{*}$ Localized is defined by Ann-Arbor classification 1-2; ${ }^{* *}$ Advanced is defined by Ann-Arbor stage III-IV; ${ }^{* * *}$ At first line or later. 
Table 2: Characteristics of LD/t-AML at diagnosis and comparison to other therapy-related AML, secondary AML and de novo AML

\begin{tabular}{|c|c|c|c|c|}
\hline & $\begin{array}{c}\text { LD/t-AML } \\
\quad n=80\end{array}$ & $\begin{array}{l}\text { Other t-AML } \\
\quad n=85\end{array}$ & $\begin{array}{l}\text { sAML } \\
n=292\end{array}$ & $\begin{array}{c}\text { De novo AML } \\
n=829\end{array}$ \\
\hline History of previous cytopenia* n (\%) & $22(28) \#$ & $13(15)$ & NA & $61(7)$ \\
\hline $\begin{array}{l}\text { History of previous documented MDS** }- \text { n } \\
(\%)\end{array}$ & $17(21)$ & NA & $235(81)$ & - \\
\hline $\begin{array}{l}\text { Delay to secondary AML*** - months } \\
\text { (median, IQR) }\end{array}$ & $60(31-106)$ & NA & NA & - \\
\hline $\begin{array}{l}\text { Age at AML diagnosis - years } \\
\text { (median, IQR) }\end{array}$ & $66(57-71)$ & $67(58-74)$ & $72(63-78)$ & $62(48-72)$ \\
\hline $\begin{array}{l}\text { ECOG PS - n (\%) } \\
0-1 \\
2-3-4 \\
\text { Not known } \\
\end{array}$ & $\begin{array}{l}36(45) \\
20(25) \\
24(30) \\
\end{array}$ & $\begin{array}{l}55(65) \\
17(20) \\
13(15) \\
\end{array}$ & $\begin{array}{c}115(39) \\
71(24) \\
106(36) \\
\end{array}$ & $\begin{array}{l}523(63) \\
150(18) \\
156(19) \\
\end{array}$ \\
\hline WBC $-.10^{9} / \mathrm{L}$ (median, IQR) & $3.8(1.7-29.2)$ & $3.3(1.7-16.4)$ & $6.2(2.1-23.1)$ & $7.9(2.6-38.8)$ \\
\hline Platelet count $-.10^{9} / \mathrm{L}$ (median, IQR) & $48(23-85)$ & $50(34-98)$ & $62(30-132)$ & $67(37-120)$ \\
\hline Bone marrow blasts $-\%$ (median, IQR) & $46(32-69)$ & $46(30-76)$ & $35(24-60)$ & $63(37-83)$ \\
\hline $\begin{array}{l}\text { FAB - n (\%) } \\
0 \\
1 \\
2 \\
3^{\S \S} \\
4 \\
5 \\
6 \\
7 \\
\text { Not defined } \\
\text { Unknown }\end{array}$ & $\begin{array}{c}6(8) \\
4(5) \\
26(33) \\
0 \\
13(16) \\
8(10) \\
9(11) \\
1(1) \\
10(12) \\
3(4)\end{array}$ & $\begin{array}{c}3(4) \\
13(15) \\
40(47) \\
1(1) \\
14(17) \\
2(2) \\
6(7) \\
3(4) \\
2(2) \\
1(1)\end{array}$ & $\begin{array}{c}10(3) \\
21(7) \\
146(50) \\
0 \\
37(13) \\
19(7) \\
15(5) \\
5(2) \\
12(4) \\
27(9)\end{array}$ & $\begin{array}{c}41(5) \\
180(22) \\
280(34) \\
13(2) \\
137(17) \\
99(12) \\
21(3) \\
13(2) \\
26(3) \\
19(2)\end{array}$ \\
\hline $\begin{array}{l}\text { Karyotype }-\mathbf{n}(\mathbf{( \% )}) \\
\text { Favorable } \\
\text { Intermediate } \\
\text { Adverse } \\
\text { Unknown }\end{array}$ & $\begin{array}{c}3(4) \\
36(45) \\
29(36) \\
12(15)\end{array}$ & $\begin{array}{c}3(4) \\
40(47) \\
38(45) \\
4(5)\end{array}$ & $\begin{array}{c}0 \\
157(54) \\
100(34) \\
35(12)\end{array}$ & $\begin{array}{c}74(9) \\
541(65) \\
180(22) \\
21(3)\end{array}$ \\
\hline $\begin{array}{l}M L L+\% \\
\text { Del } 5 / 5 q^{\%} \\
\text { Del } 7 / 7 q^{\%} \\
\text { Complex }{ }^{\%} \\
\text { Monosomal }^{\%}\end{array}$ & $\begin{array}{c}4(6) \\
11(16) \\
15(22) \\
15(22) \\
15(22)\end{array}$ & $\begin{array}{l}12(14) \\
15(18) \\
9(11) \\
19(22) \\
16(19)\end{array}$ & $\begin{array}{c}3(1) \\
49(17) \\
59(20) \\
57(20) \\
46(16)\end{array}$ & $\begin{array}{c}24(3) \\
79(10) \\
91(11) \\
107(13) \\
82(10)\end{array}$ \\
\hline
\end{tabular}

Abbreviations: MDS: myelodysplastic syndrome; FAB: French-American-British classification; $M L L$ : Mixed-lineage leukemia.

${ }^{\S}$ AML secondary to Philadelphia-negative myeloproliferative neoplasm, myelodysplastic syndrome and chronic myelomonocytic leukemia.

${ }^{\S}$ LAM3 were collected only from 2011 in our database, which implies an underrepresentation of this category.

"Defined as anemia, thrombocytopenia, neutropenia or any combination after end of LD treatment and more than six months before AML diagnosis - lymphopenia excluded.

${ }^{* *}$ Defined as documented MDS diagnosed more than six months before AML diagnosis.

*** Defined as (AML diagnosis date - LD diagnosis date).

\#For three of them, cytopenia occurred after four to seven cycles of R-chemotherapy.

$\%$ These abnormalities were present either alone or combined. 
Table 3: Time from $\mathrm{LD}$ diagnosis to $\mathrm{LD} / \mathrm{t}-\mathrm{AML}$ diagnosis according to $\mathrm{LD}$ type

\begin{tabular}{|l|c|}
\hline \multicolumn{1}{c}{ LD type $-\mathbf{n}(\%)$} & Median latency (months) \\
\hline DLBCL & 23.6 \\
MCL & 69.1 \\
BL & 37.4 \\
Other & 69.8 \\
FL & 63.5 \\
CLL & 57 \\
MALT/SALT & 65.5 \\
Lymphocytic & 15.6 \\
Unknown & 87.4 \\
Hodgkin lymphoma & 95.6 \\
T-cell lymphoma & 13.8 \\
Not known & NA \\
\hline
\end{tabular}

Abbreviations: DLBCL: diffuse large B cell lymphoma; MCL: mantle cell lymphoma; BL: Burkitt-like; FL: follicular lymphoma; CLL: chronic lymphocytic leukemia.

\section{Impact of LD characteristics and their treatment on LD/t-AML}

Age at LD diagnosis had a major impact on time from LD diagnosis to LD/t-AML diagnosis, which was longer for patients younger than 60 years old (86.2 months vs. 40.1 months; $P=0.003$ ). Time from $\mathrm{LD}$ diagnosis to $\mathrm{LD} / \mathrm{t}$-AML diagnosis was shorter for TCL, lymphocytic lymphoma, DLBCL and BL (13.8, 15.6, 23.6 and, 37.4 months respectively), intermediate for FL, MALT/SALT, MCL and CLL (63.5, 65.5, 69.1 and 57 months respectively), and longer for HL (95.6 months). Table 3 this difference in latency could in part be explained by the shorter survival of patients treated for T-NHL or aggressive NHL. Time to LD/t-AML was not significantly different when considering fludarabine-based regimens, chlorambucil, or $\operatorname{ASCT}$ (58.4, 62.4, and 93.5 months, respectively). However, this interval was significantly shorter after CHOP-like or R-containing regimens (33.6 months, $P=0.02$ and 48.6 months, $P=0.009$, respectively). Neither subtype of LD nor specific regimen used for LD treatment (including rituximab regimen vs. others) influenced the cytogenetic profile of LD/t-AML. However, there was a trend for an increased incidence of monosomal karyotypes in patients who received an ASCT ( $38 \%$ vs. $14 \%, P=0.07$ ). $53 \%$ of patients presented one or more cytopenias between end of treatment of lymphoma and diagnosis of $\mathrm{LD} / \mathrm{t}-\mathrm{AML}$. For these patients, time to LD/t-AML was shorter (31.7 vs. 79 months; $P=0.04$ ). In three cases, cytopenias occurred during lymphoma treatment: one case of neutropenia and two cases of thrombocytopenia occurred after 4,4 or 7 cycles, or R-chemotherapy, leading to treatment withdrawal or dose reduction. For these three patients, time to AML was even shorter (26.1 months). Seventeen patients (21\%) developed a documented myelodysplastic syndrome (MDS) at least six months before t-AML diagnosis.

\section{Treatment and outcome}

Treatment of LD/t-AML consisted in intensive chemotherapy $(n=48)$, azacitidine $(n=12)$, low dose cytarabine $(n=4)$, 6-mercaptopurine and low dose methotrexate $(n=3)$, or best supportive care $(n=12)$. Only three patients underwent allogeneic stem cell transplantation in complete remission (CR) after intensive chemotherapy. Characteristics of patients treated with intensive chemotherapy or azacitidine are summarized in Table 4. In the group of patients treated by azacitidine, one patient achieved $\mathrm{CR}$ and another one achieved partial remission. Median OS from LD/t-AML and from LD diagnosis after azacitidine was 12.6 months and 157 months, respectively.

When considering patients treated with intensive chemotherapy, CR, early death, and treatment failure rates were $54 \%, 13 \%$, and $33 \%$, respectively. Among the 24 patients with intermediate-risk cytogenetics, 13 (54\%) achieved CR as did 8 out of 17 patients (47\%) with adverse cytogenetics. Median OS from LD/t-AML and from LD diagnosis were 7.7 and 75.6 months, respectively.

OS from t-AML diagnosis was highly variable according to the type of LD, with AML following treatment of DLBCL, HL and TCL displaying longer OS (73.0, 24.0 and 17.7 months, respectively), compared to OS of AML following treatment of MALT/SALT, CLL, MCL, BL and FL (1.8, 3.7, 4.3, 5.8 and 8.5 months, respectively $-P=0.02$ ). Also, LD with advanced stages displayed shorter OS compared to localized stages (8.2 vs. 16.8 months, $P=0.23$ ). Similarly, number of prior treatment lines for LD was associated with a shorter median OS $(13.5,7.9$, and 6.0 months after 1,2 , or $\geq 3$ 
Table 4: Characteristics of LD/t-AML according to treatment

\begin{tabular}{|c|c|c|}
\hline & $\begin{array}{c}\text { Intensive chemotherapy } \\
n=48\end{array}$ & $\begin{array}{c}\text { Azacitidine } \\
n=12\end{array}$ \\
\hline Delay to secondary AML* - months (median, IQR) & $60(32-103)$ & $123(37-189)$ \\
\hline $\begin{array}{l}\text { Center }-\mathbf{n}(\mathbf{\%}) \\
\text { Toulouse } \\
\text { Marseille }\end{array}$ & $\begin{array}{l}18(37) \\
30(63)\end{array}$ & $\begin{array}{l}10(83) \\
2(17)\end{array}$ \\
\hline MDS prior to AML diagnosis - n (\%) & $5(10)$ & $4(33)$ \\
\hline Age at AML diagnosis - years (median, IQR) & $60(51-67)$ & $77(70-78)$ \\
\hline $\begin{array}{l}\text { ECOG PS - n (\%) } \\
0-1 \\
2-3-4 \\
\text { Not known }\end{array}$ & $\begin{array}{l}25(52) \\
9(19) \\
14(29)\end{array}$ & $\begin{array}{c}10(83) \\
0 \\
2(17)\end{array}$ \\
\hline WBC $-.10^{9} / L$ (median, IQR) & $3.2(1.8-33)$ & $2.2(1.4-7.5)$ \\
\hline $\begin{array}{l}\text { Karyotype }-\mathbf{n}(\mathbf{\%}) \\
\text { Favorable } \\
\text { Intermediate } \\
\text { Adverse } \\
\text { Unknown }\end{array}$ & $\begin{array}{c}3(6) \\
24(50) \\
17(35) \\
4(8)\end{array}$ & $\begin{array}{c}0 \\
7(58) \\
4(33) \\
1(8) \\
\end{array}$ \\
\hline $\begin{array}{l}\text { LD type - n (\%) } \\
\text { DLBCL } \\
\text { MCL } \\
\text { BL } \\
\text { FL } \\
\text { CLL } \\
\text { MALT/SALT } \\
\text { Lymphocytic } \\
\text { Hodgkin lymphoma } \\
\text { T-cell lymphoma }\end{array}$ & $\begin{array}{c}9(19) \\
2(4) \\
2(4) \\
13(27) \\
6(13) \\
1(2) \\
0 \\
8(17) \\
2(4)\end{array}$ & $\begin{array}{c}2(17) \\
0 \\
0 \\
2(17) \\
1(8) \\
1(8) \\
0 \\
2(17) \\
1(8)\end{array}$ \\
\hline $\begin{array}{l}\text { Stage at diagnosis - n (\%) } \\
\text { Localized } * * / \text { Binet A } \\
\text { Advanced } * * * / \text { Binet B-C } \\
\text { Unknown }\end{array}$ & $\begin{array}{l}30(63) \\
10(21) \\
8(17) \\
\end{array}$ & $\begin{array}{l}9(75) \\
1(8) \\
2(17)\end{array}$ \\
\hline $\begin{array}{l}\text { Treatment }-\mathbf{n}(\mathbf{\%}) \\
\text { Rituximab-containing regimen } \\
\text { Fludarabine-based } \\
\text { CHOP-like } \\
\text { Chlorambucil } \\
\text { Unknown }\end{array}$ & $\begin{array}{c}18 / 43(42) \\
4 / 43(9) \\
20 / 43(47) \\
10 / 43(23) \\
5(8)\end{array}$ & $\begin{array}{l}5 / 10(50) \\
2 / 10(20) \\
4 / 10(40) \\
2 / 10(20) \\
2(17)\end{array}$ \\
\hline $\begin{array}{l}\text { No. of treatment lines (median, min-max) } \\
2 \text { lines } \\
\geq 3 \text { lines }\end{array}$ & $\begin{array}{l}1(1-5) \\
12(25) \\
7(15)\end{array}$ & $\begin{array}{l}1(1-3) \\
1(8) \\
2(17)\end{array}$ \\
\hline Autologous stem cell transplantation - n (\%) & $16(33)$ & 0 \\
\hline
\end{tabular}

Abbreviations: MDS: myelodysplastic syndrome; NHL: non-Hodgkin lymphoma; WBC; white blood cell count.

*Defined as (AML diagnosis date - LD diagnosis date); ${ }^{* *}$ Localized is defined by Ann-Arbor classification 1-2; ${ }^{* * *}$ Advanced is defined by Ann-Arbor stage III-IV.

treatment lines, respectively), although this difference was not statistically significant. In univariate analysis, age greater than 60 years $(P=0.002)$, ECOG performance status greater than $1(P=0.0002)$, myelodysplastic syndrome prior to $\mathrm{LD} / \mathrm{t}-\mathrm{AML}(P=0.09)$, rituximab- containing regimens $(P=0.07)$, and fludarabine-based regimens or chlorambucil $(P=0.11)$ had a negative impact on OS (Table 5). In multivariate analyses for OS, only age $\left(P=0.04\right.$; HR $\left.1.06 \mathrm{CI}_{95}[1.003-1.12]\right)$ and ECOG performance status $2-3\left(P=0.04 ; \mathrm{HR} 8.0 \mathrm{CI}_{95}[1.25-51.6]\right)$ 
Table 5: Univariate analysis of overall survival for patients treated with intensive chemotherapy

\begin{tabular}{|c|c|c|}
\hline Variable & Median OS\$ (months) & $\begin{array}{c}p \\
\text { (log-rank) }\end{array}$ \\
\hline $\begin{array}{l}\text { Age } \\
<60 \text { years } \\
\geq 60 \text { years }\end{array}$ & $\begin{array}{c}16.4 \\
6.0\end{array}$ & 0.002 \\
\hline $\begin{array}{l}\text { ECOG } \\
0-1 \\
2-3 \\
\text { Not known } \\
\end{array}$ & $\begin{array}{c}16.4 \\
2.4 \\
10.1 \\
\end{array}$ & 0.0002 \\
\hline $\begin{array}{l}\text { Number of treatment lines } \\
1 \\
2 \\
\geq 3\end{array}$ & $\begin{array}{c}13.5 \\
7.9 \\
6.0\end{array}$ & 0.74 \\
\hline $\begin{array}{l}\text { Karyotype* } \\
\text { Favorable } \\
\text { Intermediate } \\
\text { Adverse }\end{array}$ & $\begin{array}{l}\text { NR } \\
7.1 \\
8.5\end{array}$ & 0.22 \\
\hline $\begin{array}{l}\text { Cytopenia prior to AML diagnosis** } \\
\text { Yes } \\
\text { No }\end{array}$ & $\begin{array}{c}16.4 \\
3.1\end{array}$ & 0.25 \\
\hline $\begin{array}{l}\text { MDS prior to AML diagnosis*** } \\
\text { Yes } \\
\text { No }\end{array}$ & $\begin{array}{r}6.3 \\
9.4 \\
\end{array}$ & 0.09 \\
\hline $\begin{array}{l}\text { White blood cell count at AML diagnosis } \\
<10.10^{9} / \mathrm{L} \\
\geq 10.10^{9} / \mathrm{L} \\
\end{array}$ & $\begin{array}{c}15.2 \\
7.4 \\
\end{array}$ & 0.30 \\
\hline $\begin{array}{l}\text { Stage at LD diagnosis } \\
\text { Indolent / Binet A } \\
\text { Aggressive / Binet B-C }\end{array}$ & $\begin{array}{c}16.8 \\
8.2 \\
\end{array}$ & 0.23 \\
\hline $\begin{array}{l}\text { Histological type of LD } \\
\text { DLBCL } \\
\text { MCL } \\
\text { BL } \\
\text { FL } \\
\text { CLL } \\
\text { MALT/SALT } \\
\text { Hodgkin lymphoma } \\
\text { T-cell lymphoma } \\
\end{array}$ & $\begin{array}{c}73.0 \\
4.3 \\
5.8 \\
8.5 \\
3.7 \\
1.8 \\
24.0 \\
17.7\end{array}$ & 0.02 \\
\hline $\begin{array}{l}\text { Center } \\
\text { Toulouse } \\
\text { Marseille } \\
\end{array}$ & $\begin{array}{r}7.3 \\
8.5 \\
\end{array}$ & 0.24 \\
\hline $\begin{array}{l}\text { Rituximab-containing regimen } \\
\text { Yes } \\
\text { No } \\
\end{array}$ & $\begin{array}{c}4.6 \\
15.2 \\
\end{array}$ & 0.07 \\
\hline $\begin{array}{l}\text { Chemotherapy type } \\
\text { CHOP-like } \\
\text { Fludarabine-based } \\
\text { Chlorambucil }\end{array}$ & $\begin{array}{c}15.0 \\
5.3 \\
7.9\end{array}$ & 0.11 \\
\hline $\begin{array}{l}\text { Autologous stem cell transplantation } \\
\text { Yes } \\
\text { No }\end{array}$ & $\begin{array}{l}7.9 \\
9.3\end{array}$ & 0.88 \\
\hline
\end{tabular}

Abbreviations: NR: not reached; MDS: myelodysplastic syndrome; NHL: non-Hodgkin lymphoma.

*According to MRC classification [37].

** Defined as anemia, thrombocytopenia, neutropenia or any combination after end of LD treatment and more than six months before AML diagnosis - lymphopenia excluded.

*** Defined as documented MDS diagnosed more than six months before AML diagnosis.

§rom AML diagnosis. 
were independent prognostic factors in patients treated by intensive chemotherapy.

\section{Outcome of LD/t-AML compared to other subtypes of secondary and t-AML}

Patients of the Toulouse University Hospital database treated by intensive chemotherapy in the same study period $(n=853)$ had a median OS of 19.7 months. Median OS was 26.1 months in de novo AML $(n=663), 4.2$ months in post-Philadelphia negative myeloproliferative neoplasm AML $(n=22), 9.4$ months in post-myelodysplastic syndrome AML $(n=64), 8.6$ months in post-chronic myelomonocytic leukemia $\operatorname{AML}(n=19)$, 13.4 months in t-AML following the treatment of solid cancer $(n=50)$, and 14.7 months when focusing on breast cancer only $(n=30)$ (Figure 1$)$.

\section{DISCUSSION}

This study shows that t-AML following the treatment of lymphoid malignancies is heterogeneous in terms of delay of onset, cytogenetic risk, response to therapy, and outcome. The recent introduction of rituximab in B-cell malignancies did not appear to change the characteristics of LD/t-AML although its delay of onset was shorter in patients who received this monoclonal antibody. Overall, prognosis of patients treated by intensive chemotherapy remains very poor.

t-AML accounted for $10.6 \%$ of all cases of AML treated with intensive chemotherapy in this period in Toulouse University Hospital, and LD/t-AML accounted for $4.1 \%$ of all cases and for $18.4 \%$ of secondary AML (including post-MDS and post-MPN AML). This result is slightly higher than the incidence reported by the Danish and Swedish registries and by the German-Austrian AMLSG group [11, 13, 18].

Despite obvious pitfalls including heterogeneity of LD subtypes and treatments, a low number of patients, and missing data due to the long period of inclusion, this retrospective study describes all consecutive cases of AML secondary to LD treatments in a recent period and contributes to define clinical characteristics and prognostic factors for this particular subtype of t-AML since most studies included various previous cancer including but not limited to LD. As expected, we found an overrepresentation of $M L L$ rearrangements, complex and monosomal karyotypes, compared to de novo AML. In particular, FAB-M6 AML was found in $11 \%$ of cases, which is unusual in large series of AML and significantly higher compared to de novo AML (3\%).

We have identified distinct profiles of $\mathrm{LD} / \mathrm{t}-\mathrm{AML}$ according to the LD subtype. Indeed, longer latency and better OS were observed in HL patients, whereas TCL or aggressive NHL patients had a shorter time to t-AML and CLL patients had the lowest median overall survival. Previous treatments and subsequent genomic or microenvironment alterations, altered immune background related to the underlying LD and treatment, age at LD diagnosis (which was a major determinant for delay from $\mathrm{LD}$ diagnosis to $\mathrm{LD} / \mathrm{t}-\mathrm{AML}$ diagnosis as already reported) [19], or genetic susceptibilities including polymorphisms in genes governing drug metabolism, DNA repair, and leukemogenesis, may account for these distinct features $[5,20]$. T-AML are genetically characterized by abnormal double-strand break repair and frequent TP53 mutations selected by previous chemotherapy, predisposing to genomic instability [9, 21-22]. Indeed, the large majority

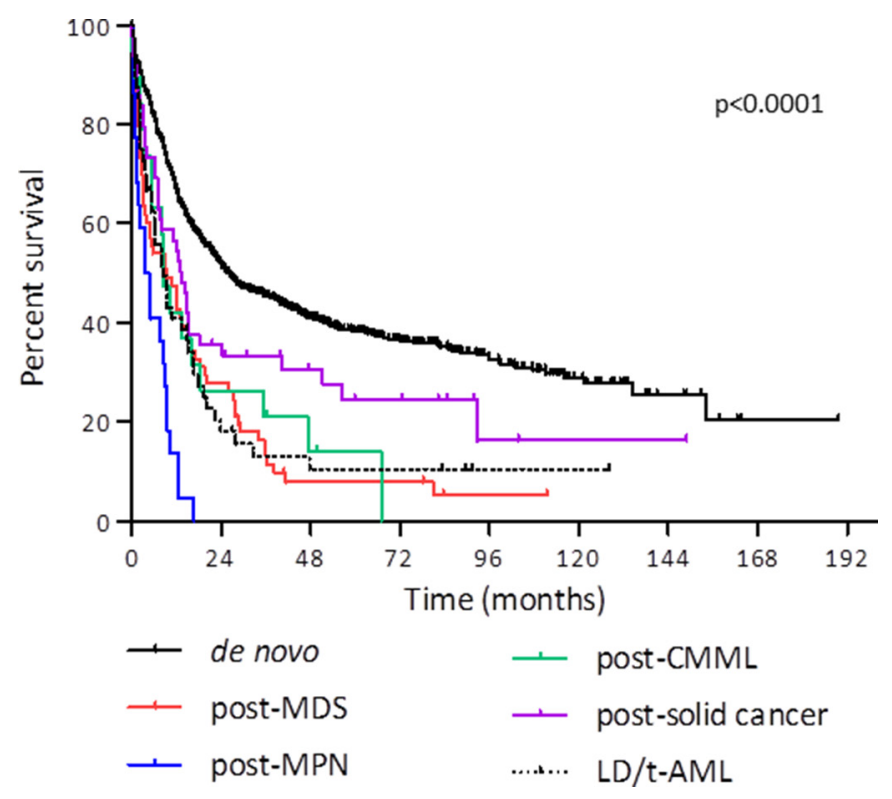

Figure 1: Overall survival after intensive chemotherapy according to AML type. 
of t-AML shows cytogenetic abnormalities indicating that chromosomal aberrations may constitute the main driver of disease in these patients [23]. In our series, few cases were molecularly annotated with FLT3-ITD found in only two of 17 cases (11.8\%) and NPM1 mutation in one of $15(6.7 \%)$. A recent study has established a genetic classification of t-AML through the sequencing of 82 genes suspected to be involved in the pathogenesis of myeloid malignancies [24]. Unfortunately, we did not provide data on SRSF2, SF3B1, U2AF1, ZRSR2, ASXL1, EZH2, BCOR, STAG2 or TP53 mutations since the sequencing of these genes was not performed throughout the study period. Additional studies are needed to determine the distribution of theses mutations and provide new elements for better understanding the pathogenesis of t-AML following lymphoid malignancies.

The risk of AML following B-CLL treatment remains controversial since some studies did not report such an association [16]. It has been suggested that the association of fludarabine with an alkylating agent may increase the incidence of t-AML and perhaps to a greater extent when combined with rituximab [25-27]. After frontline fludarabine-cyclophosphamide-rituximab (FCR) treatment for B-CLL, latency of 35 months to develop t-AML or MDS was reported. These therapyrelated myeloid neoplasms could emerge directly from prolonged myelosuppression following FCR or after achieving complete hematological recovery with latency significantly shorter in the former group (23 months vs. 42 months) [27]. However, these studies should be interpreted cautiously since the CLL- 8 randomized study comparing FCR to FC did not show any difference in the incidence of secondary AML after a median follow-up of 5.9 years [28].

Intensive chemotherapy in patients with AML secondary to previous MDS, CMML, MPN, or prior cytotoxic exposure remains unsatisfactory compared to de novo AML $[13,19]$. However, our results suggest that t-AML following treatment of solid cancer has a better outcome compared to post-MDS, post-CMML, and post-LD while post-MPN AML seems to have the worst outcome. Azacitidine has emerged as an alternative of intensive chemotherapy, especially in poor-risk patients [29-30]. Azacitidine has already been evaluated in therapy-related myeloid neoplasms with $40 \%$ overall response rate and a median OS between 9 and 21 months [31-33], which is in line with our LD/t-AML series, although the number of patients treated in our study was very low.

In conclusion, the prognosis of $\mathrm{LD} / \mathrm{t}-\mathrm{AML}$ is particularly poor whatever the treatment. Prevention of AML emergence by using a less leukemogenic regimen for lymphoid malignancies should be carefully weighed at LD diagnosis. New treatment strategies in patients with LD/t-AML and other secondary AML are urgently needed.

\section{MATERIALS AND METHODS}

\section{Patient selection}

Our study included 80 consecutive cases of t-AML secondary to NHL, HL, T-cell lymphoma and chronic lymphocytic leukemia diagnosed and treated in Toulouse University Hospital and Institut Paoli-Calmettes (Marseille) between 1997 and 2012. All patients were treated for their LD. AML secondary to myeloma or acute lymphoblastic leukemia were not considered in this study. Written informed consent was obtained from all patients in accordance with the Declaration of Helsinki, allowing the collection of clinical and biological data in an anonymized database. The cytogenetic classification for AML was in accordance with the Medical Research Council classification [33]. Treatment of AML has been described previously [30, 35-37].

\section{Statistical analyses}

We described patient characteristics using number and frequency for qualitative data and median, and interquartile range (IQR) for quantitative data. Differences were tested with Chi2 test (or Fisher's exact test in case of small expected numbers) for qualitative data and with Student $t$-test (or Mann-Whitney $\mathrm{U}$ test) for quantitative data. Complete response referred to the combination of complete response (CR) and complete response with incomplete blood count recovery (CRi) defined by international consensus criteria [38]. Early death was defined as death from any cause occurring between the start of chemotherapy and the response assessment. Treatment failure was defined as failure to achieve CR with evidence of persistent leukemia by blood and/or bone marrow examination. Overall survival (OS) was measured from the date of diagnosis to the date of death from any cause; patients not known to have died at last follow-up were censored on the date they were last known to be alive. Survival functions were estimated by the Kaplan-Meier method and differences were tested using the log-rank test. Multivariate analysis of OS was conducted using the Cox model. Age, ECOG performance status, white blood cell count (WBC) and karyotype at diagnosis, myelodysplastic syndrome prior to AML diagnosis, stage at LD diagnosis, histological type of LD, type of treatment, number of previous treatment lines, autologous stem cell transplantation, and center of diagnosis were included in the model. All reported $P$ values were two-sided, and the significance threshold was $<0.05$. Statistical analyses were performed on GraphPad Prism and STATA v13.

\section{ACKNOWLEDGMENTS}

We thank all the members of the G.A.E.L (Gaël Adolescent Espoir Leucémie) and A.G.M.O.M.P 
(Association des Greffés de Moelle Osseuse de MidiPyrénées) associations for their kind support to patients. We also thank Sir Jean Delpouy, his family and friends for his generous support. We also thank the data management unit of Toulouse University Hospital for enabling e-CRF. This work has been approved by the National Research Agency (ANR), granted by the French government under the "Investissement d'avenir" program (ANR-11PHUC-001).

\section{CONFLICTS OF INTEREST}

The authors declare no conflicts of interest related to this study.

\section{REFERENCES}

1. Vardiman JW, Harris NL, Brunning RD. The World Health Organization (WHO) classification of the myeloid neoplasms. Blood. 2002; 100:2292-302.

2. Swerdlow SH, WHO Classification of tumours of haematopoietic and lymphoid tissues. Lyon, France: IARC; 2008; pp 109-138.

3. Mistry AR, Felix CA, Whitmarsh RJ, Mason A, Reiter A, Cassinat B, Parry A, Walz C, Wiemels JL, Segal MR, Adès L, Blair IA, Osheroff N, et al. DNA topoisomerase II in therapy-related acute promyelocytic leukemia. N Engl J Med. 2005; 352:1529-38.

4. Kyle RA, Pierre RV, Bayrd ED. Multiple myeloma and acute myelomonocytic leukemia: report of four cases possibly related to melphalan. N Engl J Med. 1970; 283:1121-5.

5. Pedersen-Bjergaard J. Insights into leukemogenesis from therapy-related leukemia. N Engl J Med. 2005; 352:1591-4.

6. Pui CH, Behm FG, Raimondi SC, Dodge RK, George SL, Rivera GK, Mirro J Jr, Kalwinsky DK, Dahl GV, Murphy SB. Secondary acute myeloid leukemia in children treated for acute lymphoid leukemia. N Engl J Med. 1989; 321:136-42.

7. Qian Z, Joslin JM, Tennant TR, Reshmi SC, YoungDJ, Stoddart A, Larson RA, Le Beau MM. Cytogenetic and genetic pathways in therapy-related acute myeloid leukemia. Chem Biol Interact. 2010; 184:50-7.

8. Brassat D, Recher C, Waubant E, Le Page E, RigalHuguet F, Laurent G, Edan G, Clanet M. Therapy-related acute myeloblastic leukemia after mitoxantrone treatment in a patient with MS. Neurology. 2002; 59:954-5.

9. Wong TN, Ramsingh G, Young AL, Miller CA, Touma W, Welch JS, Lamprecht TL, Shen D, Hundal J, Fulton RS, Heath S, Baty JD, Klco JM, et al. Role of TP53 mutations in the origin and evolution of therapy-related acute myeloid leukaemia. Nature. 2015; 518:552-5.

10. Morton LM, Dores GM, Tucker MA, Kim CJ, Onel K, Gilbert ES, Fraumeni JF Jr, Curtis RE. Evolving risk of therapy-related acute myeloid leukemia following cancer chemotherapy among adults in the United States, 1975-2008. Blood. 2013; 121:2996-3004.

11. Hulegårdh $\mathrm{E}$, Nilsson $\mathrm{C}$, Lazarevic $\mathrm{V}$, Garelius $\mathrm{H}$, AntunovicP, Rangert Derolf Å, Möllgård L, Uggla B, Wennström L, Wahlin A, Höglund M, Juliusson G, Stockelberg D, et al. Characterization and prognostic features of secondary acute myeloid leukemia in a population-based setting: a report from the Swedish Acute Leukemia Registry. Am J Hematol. 2015; 90:208-14.

12. Fianchi L, Pagano L, Piciocchi A, Candoni A, Gaidano G, Breccia M, Criscuolo M, Specchia G, Maria Pogliani E, Maurillo L, Aloe-Spiriti MA, Mecucci C, Niscola P, et al. Characteristics and outcome of therapy-related myeloid neoplasms: Report from the Italian network on secondary leukemias. Am J Hematol. 2015; 90:E80-5.

13. Granfeldt Østgård LS, Medeiros BC, Sengeløv $\mathrm{H}$, NørgaardM, Andersen MK, Dufva IH, Friis LS, Kjeldsen E, Marcher CW, Preiss B, Severinsen M, Nørgaard JM. Epidemiology and Clinical Significance of Secondary and Therapy-Related Acute Myeloid Leukemia: A National Population-Based Cohort Study. J Clin Oncol. 2015; 33:3641-9.

14. Castillo JJ, Olszewski AJ, Hunter ZR, Kanan S, Meid K, Treon SP. Incidence of secondary malignancies among patients with Waldenström macroglobulinemia: An analysis of the SEER database. Cancer. 2015; 121:2230-6.

15. Morton LM, Curtis RE, Linet MS, Bluhm EC, Tucker MA, Caporaso N, Ries LA, Fraumeni JF Jr. Second malignancy risks after non-Hodgkin's lymphoma and chronic lymphocytic leukemia: differences by lymphoma subtype. J Clin Oncol. 2010; 28:4935-44.

16. Royle JA, Baade PD, Joske D, Girschik J, Fritschi L. Second cancer incidence and cancer mortality among chronic lymphocytic leukaemia patients: a population-based study. Br J Cancer. 2011; 105:1076-81.

17. Hallek M. Chronic lymphocytic leukemia: 2015 Update on diagnosis, risk stratification, and treatment. Am J Hematol. 2015; 90:446-60.

18. Kayser S, Döhner K, Krauter J, Köhne CH, Horst HA, Held G, von Lilienfeld-Toal M, Wilhelm S, Kündgen A, Götze K, Rummel M, Nachbaur D, Schlegelberger B, et al. The impact of therapy-related acute myeloid leukemia (AML) on outcome in 2853 adult patients with newly diagnosed AML. Blood. 2011; 117:2137-45.

19. Ornstein MC, Mukherjee S, Mohan S, Elson P, Tiu RV, Saunthararajah Y, Kendeigh C, Advani A, Kalaycio M, Maciejewski JP, Sekeres MA. Predictive factors for latency period a prognostic model for survival in patients with therapy-related acute myeloid leukemia. Am J Hematol. 2014; 89:168-73.

20. Hake CR, Graubert TA, Fenske TS. Does autologous transplantation directly increase the risk of secondary leukemia in lymphoma patients? Bone Marrow Transplant. 2007; 39:59-70. 
21. Jacoby MA, De Jesus Pizarro RE, Shao J, Koboldt DC, Fulton RS, Zhou G, Wilson RK, Walter MJ. The DNA double-strand break response is abnormal in myeloblasts from patients with therapy-related acute myeloid leukemia. Leukemia. 2014; 28:1242-51.

22. Shih AH, Chung SS, Dolezal EK, Zhang SJ, AbdelWahab OI, Park CY, Nimer SD, Levine RL, Klimek VM. Mutational analysis of therapy-related myelodysplastic syndromes and acute myelogenous leukemia. Haematologica. 2013; 98:908-12.

23. Karimi M, Nilsson C, Dimitriou M, Jansson M, Matsson H, Unneberg P, Lehmann S, Kere J, Hellström-Lindberg E. High-throughput mutational screening adds clinically important information in myelodysplastic syndromes and secondary or therapy-related acute myeloid leukemia. Haematologica. 2015; 100:e223-5.

24. Lindsley RC, Mar BG, Mazzola E, Grauman PV, ShareefS, Allen SL, Pigneux A, Wetzler M, Stuart RK, Erba HP, Damon LE, Powell BL, Lindeman N, et al. Acute myeloid leukemia ontogeny is defined by distinct somatic mutations. Blood. 2015; 125:1367-76.

25. Morrison VA, Rai KR, Peterson BL, Kolitz JE, EliasL, Appelbaum FR, Hines JD, Shepherd L, Martell RE, LarsonRA, Schiffer CA. Impact of therapy With chlorambucil, fludarabine, or fludarabine plus chlorambucil on infections in patients with chronic lymphocytic leukemia: Intergroup Study Cancer and Leukemia Group B 9011. J Clin Oncol. 2001; 19:3611-21.

26. Colović M, Suvajdžić N, Janković G, Tomin D, Colović N, Fekete MD, Palibrk V. Therapy-related myelodysplastic syndrome and acute myeloid leukemia in patients with chronic lymphocytic leukemia treated with fludarabine and cyclophosphamide. Biomed Pharmacother. 2011; 65:319-21.

27. Zhou Y, Tang G, Medeiros LJ, McDonnell TJ, Keating MJ, Wierda WG, Wang SA. Therapy-related myeloid neoplasms following fludarabine, cyclophosphamide, and rituximab (FCR) treatment in patients with chronic lymphocytic leukemia/small lymphocytic lymphoma. Mod Pathol. 2012; 25:237-45.

28. Fischer K, Bahlo J, Fink AM, Goede V, Herling CD, Cramer P, Langerbeins P, von Tresckow J, Engelke A, Maurer C, Kovacs G, Herling M, Tausch E, et al. Long-term remissions after FCR chemoimmunotherapy in previously untreated patients with CLL: updated results of the CLL8 trial. Blood. 2016; 127:208-15

29. Dombret H, Seymour JF, Butrym A, Wierzbowska A, Selleslag D, Jang JH, Kumar R, Cavenagh J, Schuh AC, Candoni A, Récher C, Sandhu I, Bernal del Castillo T, et al. International phase 3 study of azacitidine vs conventional care regimens in older patients with newly diagnosed AML with $>30 \%$ blasts. Blood. 2015; 126:291-9.

30. Bories P, Bertoli S, Bérard E, Laurent J, Duchayne E, SarryA, Delabesse E, Beyne-Rauzy O, Huguet F, RécherC. Intensive chemotherapy, azacitidine, or supportive care in older acute myeloid leukemia patients: an analysis from a regional healthcare network. Am J Hematol. 2014; 89:E244-52.

31. Fianchi L, Criscuolo M, Lunghi M, Gaidano G, Breccia M, Levis A, Finelli C, Santini V, Musto P, Oliva EN, Leoni P, Aloe Spiriti A, D'Alò F, et al. Outcome of therapy-related myeloid neoplasms treated with azacitidine. J Hematol Oncol. 2012; 5:44.

32. Bally C, Thépot S, Quesnel B, Vey N, Dreyfus F, Fadlallah J, Turlure P, de Botton S, Dartigeas C, de RenzisB, Itzykson R, Fenaux P, Adès L. Azacitidine in the treatment of therapy related myelodysplastic syndrome and acute myeloid leukemia (tMDS/AML): a report on 54 patients by the Groupe Francophone Des Myelodysplasies (GFM). Leuk Res. 2013; 37:637-40.

33. Duong VH, Lancet JE, Alrawi E, Al-Ali NH, Perkins J, FieldT, Epling-Burnette PK, Zhang L, List AF, Komrokji RS. Outcome of azacitidine treatment in patients with therapyrelated myeloid neoplasms with assessment of prognostic risk stratification models. Leuk Res. 2013; 37:510-5.

34. Grimwade D, Hills RK, Moorman AV, Walker H, Chatters S, Goldstone AH, Wheatley K, Harrison CJ, Burnett AK; National Cancer Research Institute Adult Leukaemia Working Group. Refinement of cytogenetic classification in acute myeloid leukemia: determination of prognostic significance of rare recurring chromosomal abnormalities among 5876 younger adult patients treated in the United Kingdom Medical Research Council trials. Blood. 2010; 116:354-65.

35. Bertoli S, Bérard E, Huguet F, Huynh A, Tavitian S, Vergez F, Dobbelstein S, Dastugue N, Mansat-De Mas V, Delabesse E, Duchayne E, Demur C, Sarry A, et al. Time from diagnosis to intensive chemotherapy initiation does not adversely impact the outcome of patients with acute myeloid leukemia. Blood. 2013; 121:2618-26.

36. Prébet T, Jean E, Autret A, Charbonnier A, Rey J, EtienneA, D'incan E, Fürst S, Arnoulet C, Blaise D, Vey N. Combination of cytarabine and topotecan in patients treated for acute myeloid leukemia with persistent disease after frontline induction. Leuk Lymphoma. 2012; 53:2186-91.

37. Devillier R, Bertoli S, Prébet T, Huguet F, Etienne A, Charbonnier A, Rey J, Delabesse E, D'Incan E, Huynh A, Blaise D, Récher C, Vey N. Comparison of 60 or $90 \mathrm{mg} / \mathrm{m}$ of daunorubicin in induction therapy for acute myeloid leukemia with intermediate or unfavorable cytogenetics. Am J Hematol. 2015; 90:E29-30.

38. Döhner H, Estey EH, Amadori S, Appelbaum FR, Büchner T, Burnett AK, Dombret H, Fenaux P, Grimwade D, Larson RA, Lo-Coco F, Naoe T, Niederwieser D, et al. Diagnosis and management of acute myeloid leukemia in adults: recommendations from an international expert panel, on behalf of the European LeukemiaNet. Blood. 2010; 115:453-74. 